\title{
Death Donation: The Position of Higher Courts on the Examples of Cases Against Latvia and Russia
}

\author{
Gerasimenko N.S. \\ Private Educational Institution of Further Professional Education "Aktion-MCFER" \\ Moscow, Russia \\ gerasimenkon@bk.ru
}

\begin{abstract}
The author analyzed the decisions of European Court of Human Rights and Constitutional Court of the Russian Federation, made according to the cases, connected with a person's organs and tissues donorship after death for their transplantation in order to define key, not regulated by the authority questions. In all cases state authorities-defendants stated that an intrusion upon applicants' privacy in terms of organs or tissues seizure from the bodies of their relatives after death without their direct consent, given while relatives were alive, or prior informed consent of the applicants, correspond with the criterion, which is defined in item 2 of article 81 in Convention for the Rights and Fundamental Freedoms Protection. The plot of the claims, presented for consideration at European Court of Human Rights according to the discussed decisions, have much in common. In all cases state authoritiesdefendants stated that an intrusion upon applicants' privacy in terms of organs or tissues seizure from the bodies of their relatives after death without their direct consent, given while relatives were alive, or prior informed consent of the applicants, correspond with the criterion, which is defined in item 2 of article 81 in Convention for the Rights and Fundamental Freedoms Protection. Having analyzed the materials of the cases and the decisions made by the courts, the author outlined the key problems legislative of these issues regulation.
\end{abstract}

Keywords-european court of human rights; constitutional court of the russian federation; donation; presumption of consent; transplantation.

\section{INTRODUCTION}

The opportunity to use organs or tissues from a posthumous donor for transplantation is, undoubtedly, the greatest achievement of humanity, which helps to save lives of people and improve their health. We agree with the claim of the National Academy of sciences of the United States of America, which proves that posthumous organs and tissues donorship for transplantation is "medically effective and ethically acceptable approach to reduce the gap, which exists and will exist in the future between demand and available offer of organs for transplantation” [1]. At the same time, with obvious benefit and importance for humanity, transplantology development as a science and the sphere of biology and medicine caused both social and juridical problems.

The author analyzed the decisions of European Court of Human Rights and Constitutional Court of the Russian
Federation, made according to the cases, connected with a person's organs and tissues donorship after death for their transplantation in order to define key, not regulated by the authority questions.

The plot of the claims, presented for consideration at European Court of Human Rights according to the discussed decisions, have much in common. In all cases state authoritiesdefendants stated that an intrusion upon applicants' privacy in terms of organs or tissues seizure from the bodies of their relatives after death without their direct consent, given while relatives were alive, or prior informed consent of the applicants, correspond with the criterion, which is defined in item 2 of article 81

Convention for the Rights and Fundamental

Freedoms Protection. In accordance with this article "the intrusion by public authority upon somebody's privacy is not allowed, except the cases, when such intrusion is provided by the law and is necessary in a democratic society in order to protect health of other people or their rights and freedoms" [2]. Authorities of states-defendants insisted that organs and tissues seizure was held according to inter-state legislation. Both in Latvian Republic and in Russia presumption of assent functions, according to which only "the disagreement of the dead person was necessary, expresses before his or her death, or the absence of direct disagreement expressed by close relatives, before tissues seizure" [3]. On this basis the authorities followed the position that organs and tissues seizure, realized without active will expression concerning posthumous donation, doesn't contradict with the law. Moreover, it was underlined that "presumption of assent is based, on the one hand on the fact that it is not humanly to ask relatives about organs (tissues) seizure, when the person is dead, or before the operation or other therapeutic events and on the other hand, it is based on a supposition, approved by real state of medicine in the country, that at a current stage of transplantology development it is impossible to provide will expression of the mentioned people after a person's death within the period, which provides transplant preservation"[4]. At the same time, analyzing the experience of some families, the members of which faced the necessity to make the decision on a posthumous organs and tissues donorship, some authors came to the conclusion that regardless of the fact that family members, making such decisions feel great 
responsibility, most of them accepted organs "donorship" as the form of "consolation" during sorrow [5]. The results of the same research works showed that consent to donorship doesn't prevent and doesn't provide sorrow process [6].

\section{ReSEARCH Methodology}

Methodological basis of the research formed general scientific and specific scientific methods, used in jurisprudence: analysis, synthesis, system-structural approach to the ratio analysis of general, specific and separate in the legislation of the Russian Federation, formal-dogmatic and comparative- juridical methods. These methods use helped to reveal juridical positions of European Court of Human Rights and Constitutional Court of the Russian Federation on the problem of posthumous organs and tissues donorship for transplantation and define the ways of this problem solution.

The empiric basis of the research formed the Constitution of the Russian Federation, Latvian Republic and Russian legislation, decisions of European Court of Human Rights and Constitutional Court of the Russian Federation. Special attention is given to national and international periodical publications concerning the questions of posthumous organs and tissues donorship.

\section{RESULTS}

The questions of posthumous organs and tissues donorship for their further transplantation to a person demand further detailed legislative consideration and development.

In our opinion, it is reasonable to substituted presumption of consent for presumption of "received consent". This substitution will help Russian Federation citizen to express their will concerning the questions, connected with person's organs and tissues seizure after death for transplantation. It is obvious that adoption of "disagreement presumption" on legislative level would decrease the amount of cases of posthumous organs and tissues seizure by medical worker for their further transplantation to recipients, but would help to observe society and state interests balance in terms of low law knowledge among population.

It is fair and urgent that a legislator offers to introduce the register of donors, recipients and "imported" organs. Such kind of registers at a legislative level would help to fix and then to reveal and take into consideration the will of every citizen concerning his organs or tissues seizure after death for transplantation.

Elberte's appeal against Latvian Republic. In 2001 the applicant's husband died on his way to the hospital because of injuries got in a car accident. During the necropsy court expert, according to his words, checked the passport of the deceased person and saw that there was no refusal mark concerning organs and tissues seizure in it. Only then he took the tissues.

The applicant became aware of tissues seizure from her husband's body two years later from the police, after a criminal case institution, connected with illegal organs and tissues seizure in order to give to one of pharmaceutical companies, which was abroad, during almost ten years and about tissues seizure from the body of a dead husband.

During a criminal case consideration the investigation was stopped several times and then it was continued.

The investigation stated that medical center in Latvia, where seizure was held, bought medical equipment and other medical instruments for the money. Moreover, it was proved that "human tissues were taken not for transplantation, but for the preparations modification, which were supplied back to Latvian Republic and other countries" [3].

Authorities of the state-defendant underlined that according to Latvian legislation, concerning posthumous donorship, wasn't violated, as according to presumption of assent, her permission for tissues seizure after her husband's death wasn't demanded. Moreover, the authorities claimed that medical workers don't have to inform relatives of the planned organs and tissues seizure from the bodies of their relatives after death. The authorities stated that "tissues seizure was held in order to save or improve the lives of other people" [3]. At the same time state structures supported the opinion of the court, expressed during criminal proceedings, concerning the fact that "tissue was taken because of common to all mankind ideas in order to improve health state of other people and in order to make their lives longer" [3].

The authority of Latvia came to the conclusion that the applicant had to inform the doctor about her refusal to take organs or tissues of her dead husband, if she really was against, as timely refusal is a duty and responsibility of the closest relatives of a dead person. However, in this context reasonable was the claim of $\mathrm{R}$. Brownsword, who underlined that to assume tissues and organs seizure agreement after a person's death on the basis of omission, not refusal from such seizure, is a fiction and that such scheme approval can be a fraud and agreement is used for unjustified defense [7].

Petrova's appeal against Latvian Republic. In May 2002 after a car accident, being several days in coma and after cranial trepanation the applicant's son died. After death pronouncement kidneys seizure for transplantation and spleen seizure for compatibility tests with recipients' blood plasma were realized. As the applicant claims, medical personnel didn't ask her agreement for her son's organs seizure after death. They also didn't ask about her son's opinion, concerning a posthumous donorship for his organs and tissues. The applicant discovered about her son's organs seizure 9 months later from the report of forensic medical examination.

After her several appeals about illegal organs seizure the applicant received the reports, which said that when her son was alive he didn't express any refusal concerning his organs and tissues seizure for transplantation. The applicant and other close relatives also didn't express any refusal concerning this question till the moment of posthumous donorship. According to the words of medical personnel "there were no close relatives or the applicant herself in the hospital when her son died and as the organs seizure should be held quickly, there was no any opportunity to get consent from the relatives for organs and tissues seizure or refusal to realize it" [8]. 
Sablina's appeal and others against Russia. The appeal of Sablina Elena Vladimirovna was directed to European Court of Human Rights in December, 2015. As during the scientific article writing the case was on the stage of consideration, the author analyzed material of the case. The applicants were the following: Alina Sablina's mother and her two grandmothers.

The materials of the case show that in 2014 Alina Sablina sank into coma after a car accident. 6 days after the accident the death was certified, as a result of cerebrum death, according to the set legislation of the Russian Federation. The applicants discovered about Alina's organs seizure a month after the death while studying the materials of penal case from the report of forensic medical examination.

All court instances, where the applicants went, claimed held posthumous organs seizure legal and corresponding with legislation.

In 2016 the applicants referred to Constitutional Court of the Russian Federation and challenged the constitutional character of article 8 in the Law of the Russian Federation, on December, 22, 1992 № 4180-1 “On organs and (or) tissues transplantation". According to this article it is forbidden to take the organs and tissues of a dead person, if medical personnel knows the information, that a potential donor or his relatives or legal representative expressed their refusal to the organs and tissues seizure after death for further transplantation.

In order to reveal juridical position of Constitutional Court of the Russian Federation concerning this problem we would consider court decision on this case.

\section{Juridical position of Constitutional Court of the Russian Federation concerning the problem of organs and tissues seizure}

The appeal of the applicants about not constitutional character of article 8 of the Law on transplantation Constitutional Court of the Russian Federation was declared unacceptable.

Constitutional Court of the Russian Federation decreed 10.02.2016 № 224-O “On dismissal of an appeal ...”" (further - Designation № 224-O), in which it mentioned, that this question had been already considered by the court and it was stated that "in case of such kind of medical intervention, as organs and (or) tissues transplantation from one person to another - in terms of possible conflict of their interests- the main aim is to achieve proper, not violating the rights of both sides, balance of constitutionally important values and protected rights, predicts the content of juridical regulation in this sphere, which should take into consideration moral, social and other aspects of this kind of medical intervention" (Designation of December, 4, 2003 № 459-O, further Designation № 459-O) [10].

Constitutional Court of the Russian Federation was guided by the fact that in Russian the presumption of consent is realized. All criteria of presumption of consent are formed in article 8 of transplantation Law, which is officially published. The applicants had an opportunity to get acquainted with the law and inform medical personnel about their refusal concerning organs and tissues seizure from their dead relatives for transplantation.

In Designation № 459-O Constitutional Court of the Russian Federation came to the following conclusion: "article 8 of the Law of the Russian Federation "On human being's organs and (or) tissues transplantation" is not uncertain or ambiguous and can't be considered as violating constitutional rights of citizen" [10].

It should be noted that in Designation № 459-O Constitutional Court of the Russian Federation defined the necessity of more detailed questions regulation, which condition the procedure of will expression concerning posthumous organs or tissues seizure for transplantation. Legislator realized such regulation defining in article 47 of the Federal Law (November, 21, 2011) № 323-FZ "On the basis of citizens' health protection in the Russian Federation", that "adult capable citizen can orally before witnesses or in written form verified by the head of medical establishment or notarially, express his will concerning organs and tissues seizure from his organism after his death for transplantation in the order set by the legislation of the Russian Federation". In case of will expression absence the refusal can be expressed by a dead person's husband (wife), one of close relatives (children, parents, adopted, adoptive parents, brothers and sisters, grand children, a grandfather or a grandmother)" [11].

Considering the appeal of Sablina case, Constitutional Court of the Russian Federation came to the conclusion that the applicants asked to change the model of "the supposed consent" presumption for "received consent" presumption, but this is out of court jurisdiction and is the function of a legislator.

The position of the Constitutional court about the fact that article 8 of the Law of the Russian Federation (December, 22, 1992) № 4180-1 “On a human being’s organs and (or) tissues transplantation" can't be considered as constitutional rights violating, was supported by the Russian Federation authorities, which in 2016 communicated the appeal on Sablina case and which in 2017 presented remarks on this case admissibility. In paragraph 10 of the Russian Federation authorities' remarks it was specified that in 2003 Constitutional Court of the Russian Federation checked the constitutional character of theses in the Law of the Russian Federation "On a human being's organs and (or) tissues transplantation" and it was stated that the theses of this Law don't violate constitutional rights of citizen [4].

\section{Juridical position of the European Court of Human Rights on the problem of organs and tissues seizure}

All applicants of the considered cases thought that their right for private and family life respect was violated, in terms of illegal organs and tissues seizure from the bodies of their dead relatives without active applicants' consent.

In both considered cases against Latvia the European Court of Human Rights acknowledged the fact "of interference into the applicant's right realization for personal life respect, provided by article 8 of Convention for the Protection of 
Human Rights and Fundamental Freedoms" [8]. At the same time, the European Court of Human Rights mentioned that during the period of the cases consideration the legislation of Latvian Republic provided the right for consent or refusal expression concerning posthumous organs and tissues seizure for their transplantation both by the person himself and his close relatives. For the will expression citizen of Latvia had to refer to Office of Citizenship and Migration Affairs in Latvia. The expresses will expression had a juridical power in case of registration in a special register. If a person didn't express his or her will while being alive and if his or her relatives also didn't express their objections, organs and tissues use after the patient's biological death or brain death was considered legal.

However, the applicants considered their right for personal and family life respect violated in terms of the absence of created in the country conditions for opinion expression concerning the questions of posthumous organs and tissues seizure for transplantation. The European Court of Human Rights had the questions for "Latvian Republic legislation quality" and came to the conclusion that legislation, which regulated this question, wasn't formulated "sufficiently clear and didn't provide complete juridical protection from lawlessness"[8], which led to article 8 violation of Convention for the Protection of Human Rights and Fundamental Freedoms. At the same time, we agree that in terms of the number of transplanted organs increase from dead donors, it is important to create juridical norms, which would regulate ethical questions, connected with organs and tissues seizure for transplantation after death [13].

In cases against Latvia apart from article 8 violation there was the question of article 3 violation, with which the European Court of Human Rights agreed, as "caused sufferings were humiliating in article 3 violation of " Convention for the Protection of Human Rights and Fundamental Freedoms [4]. Moreover, in the opinion of the jurisconsults abroad, who analyzed the position of the European Court of Human Rights concerning these cases against Latvia, the decision of the court created the question connected with the relatives' rights character and volume for consent to organs and tissues seizure after the death of relatives. The court decision, in the opinion of jurisconsults, means that the states- members of Council of Europe should clearly define the volume of relatives' rights for consent to donorship or refusal in case if this right is regulated by the law, the same as the duty to explain these rights to relatives [14].

Speaking about juridical position of the European Court of Human Rights concerning "Sablina and others against Russia" case, during the scientific article writing this case was on the stage of commutation and was considered by the court. It should be noted that the court would consider not only violation of articles 3 and 8 in Convention for the Protection of Human Rights and Fundamental Freedoms, but also article 6 violation, which provides the right of every person to have a fair trial, in terms of the fact that the action at law was in a close regime and judicial orders were not announced in public. In the opinion of the applicants, there was one more law violation during the trial, which was demonstrated in prosecuting attorney participation from the side of the accused people and it lead to the principle of equality violation.

Taking into account the fact that the practice of European Court of Human Rights has precedential character, we can suppose that the principles, which were created by the court in the considered cases against Latvian Republic would be used during Sablina and others against Russia case consideration and there would be violated rights acknowledgement of the applicants according to Alina Sablina case.

\section{CONCLUSION}

The considered decisions of European Court of Human Rights analysis helps to come to the definite conclusion concerning the existing gaps in legislation connected with posthumous organs or tissues donorship for their further transplantation.

Conventional principles of the rights for personal and family life respect and the patients with terminal stage of organs damage provision, who are in the waiting list for transplantation, depend on how legislator regulates the questions, concerning posthumous organs or tissues donorship for transplantation.

The author expresses his gratitude to candidate of medicine, surgeon of "Moscow regional scientific-research clinical Institute names after M.F. Vladimirskiy" S.S. Meshcherin, who helped to improve this article.

\section{References}

[1] Institute of Medicine, National Academy of Sciences. Non-heartbeating organ transplantation: Medical and ethical issues in procurement. Washington, DC: National Academy Press. 1997.

[2] Convention for the Protection of Human Rights and Fundamental Freedoms (adopted in Rome 04.11.1950.) (with changes 13.05.2004) (together with "Protocol № 1» (signed in Paris 20.03.1952), "Protocol № 4 on some rights and freedoms provision together with those, which are already included into Convention and the first Protocol to it" (signed in Strasbourg 16.09.1963), "Protocol № 7» (signed in Strasbourg 22.11.1984)). Legislation of the Russian Federation collection. 2001; 2, 163.

[3] European Court of Human Rights resolution 13.01.2015 «Elberte against Latvian Republic» case (appeal № 61243/08). URL: http://www.echr.ru/documents/doc/2440800/2440800-002.htm

[4] Remarks of the Russian Federation authorities concerning the admissibility of Sablina and other against Russia case. URL: http://sutyajnik.ru/documents/5047.pdf

[5] Kentish-Barnes N, Cohen-Solal Z, Souppart V et al. Being convinced and taking responsibility: a qualitative study of family members' experience of organ donation decision and bereavement after brain death. Crit Care Med. doi: 10.1097/CCM.0000000000003616

[6] Cleiren MP, Van Zoelen AA. Post-mortem organ donation and grief: a study of consent, refusal and well-being in bereavement. Death Stud. doi: 10.1080/07481180290106607

[7] R. Brownsword, 'The Cult of Consent: Fixation and Fallacy', King's College Law Journal. 2004, 15(2), 233.

[8] European Court of Human Rights resolution 24.06.2014 "Petrova against Latvian Republic" case (appeal № 4605/05). URL: http://www.consultant.ru/ cons/cgi/onlin

[9] Constitutional court of the Russian Federation order 10.02.2016 № 224-O "On refusal to consider the appeals of Biryukova Tatyana Mikhaylovna, Sablina Elena Vladimirovna and Sablina Nelli Stepanovna concerning their constitituonal rights violatiuon with article 8 of the Law of the Russian Federation статьей "On human being's organs and (or) tissues transplantation”. URL: 
http://www.consultant.ru/document/cons_doc_LAW_194949.

[10] Constitutional court of the Russian Federation order 04.12.2003 N 459-

$\mathrm{O}$ "On refusal to consider Saratov regional court inquiry concerning constitutional character check of article 8 of the Law of the Russian Federation "On human being's organs and (or) tissues transplantation". URL:

http://www.consultant.ru/document/cons_doc_LAW_46696/\#dst10001 3.

[11] Federal law "On the basis of health protection of the Russian Federation citizen” 21.11.2011 № 323-FZ (reduction 29.05.2019 № 119-FZ) "Consultant Plus" legal reference system.

[12] "Sablina and others against Russia" case - facts and questions (appeal № 4460/16). URL: http://sutyajnik.ru/documents/5021.html.

[13] Barbara G. Organ Donation After Circulatory Death: Ethical Issues and International Practices. Anesthesia \& Analgesia. 2019, vol. 128, 2, pp. 280-285. doi: 10.1213/ANE.0000000000003448

[14] Alexsandr S. Kuznetsov. Russian Professor's meeting. Russian Journal of Physical Education and Sport. 2019, 14(1), pp. 17-22. DOI: DOI 10.14526/2070-4798-2019-14-1-18-24

[15] Edward S. Dove, Agomoni Ganguli Mitra, Graeme T. Laurie, Catriona McMillan and Samuel Taylor-Alexander. Elberte v. Latvia: Whose tissue is it anyway - Relational autonomy or the autonomy of relations? doi: $10.1177 / 0968533215618853$ 